Original Article

\title{
PRITHVI MAHABHUTA DOMINANT CHARACTERS IN PUGAPHALA (ARECA CATECHU LINN.) SCIENTIFICALLY ASSESSED THROUGH PHARMACOGNOSY AND PHARMACEUTICAL CHEMISTRY
}

\author{
KAMLA MOOND ${ }^{1 *}$, HITESH VYAS ${ }^{2}$, HARISHA C. R. ${ }^{3}$, V. J. SHUKLA ${ }^{4}$
}

1,2Department of Basic Principles, ${ }^{3}$ Department of Pharmacognosy, ${ }^{4}$ Department of Pharmaceutical Chemistry, I. P. G. T and R. A., GAU, Jamnagar, Gujarat, India

Email: prateek.jain246@gmail.com

Received: 21 Apr 2018, Revised and Accepted: 10 Jun 2018

\begin{abstract}
Objective: The Areca catechu L. is a tropical fruit, which is also called betel nut and is widely distributed in different parts of the world. Areca catechu $\mathrm{L}$ is used for various treatment aliments in the form of various preparations especially in powdered form and it used extensively in Ayurveda to treat Mukhavikara, Aruchi, Yonishaithilya, Shvetapradara etc. Areca nut is commonly used as betel nut or supari, as it is often chewed wrapped in betel leaves (Paan). The aim is to assessment of Mahabhautika dominance in Pugaphala by pharmacognostical and pharmaceutical study.
\end{abstract}

Methods: Microscopic, macroscopic study and phsico-chemical analysis of Pugaphala Churna.

Results: In present study Pugaphala was selected as a Parthiva dominant drug according to its Rasa Panchaka, after that its Mahabhautika dominancy was assessed by pharmacognostical and pharmaceutical study and results also support that in Pharmaceutical study loss on drying is $4.4 \% \mathrm{w} / \mathrm{w}$, in Pharmacognostical study Rhomboidal crystal, Lignified scleroid etc. were found these characters also showed that Pugaphala is having dominancy of Prithvi Mahabhuta.

Conclusion: Prithvi dominancy in Pugaphala is scientifically assessed by Pharmacognostical and Pharmaceutical study.

Keywords: Pugaphala, Prithvi Mahabhuta, Pharmacognosy, Pharmaceutical study

(c) 2018 The Authors. Published by Innovare Academic Sciences Pvt Ltd. This is an open access article under the CC BY license (http://creativecommons.org/licenses/by/4.0/) DOI: http://dx.doi.org/10.22159/ijcpr.2018v10i4.28473

\section{INTRODUCTION}

The Areca Nut is the seed of the areca palm (Areca catechu), which grows in much of the tropical Pacific, Asia, and parts of east Africa. Areca nut (Areca catechu) is commonly used as an ingredient of betel quid, which also includes leaf of the creeping vine piper betel and lime with or without tobacco. The plant is tall, slender, unbranched palm with a crown of leaves.

In Ayurvedic medicine, betel nut is used as a Diuretic, Digestive, Anthelmintic, Astringent, cardiotonic and used extensively in Ayurveda to treat Mukhavikara, Aruchi, Yonishaithilya, Shvetapradara etc.

Areca nut forms an essential requisite for several religious and social ceremonies and its use dates back to Vedic period with high antiquities. People in India and many parts of Asia are using areca nut. Reference to areca nut is in Rig-Veda (2000 BC). Dhanwantari Nighantu an ancient text of Indian system of medicine mentions the use of areca nut (Puga) as one of the five natural aromatics (Panchasugandhikam) with pepper, clove, nutmeg and camphor.

The use of betel nut, as a masticator by humans has been known since the 4th century AD in different parts of the world. In old Indian scripts, such as Vagbhatta (4th century) and Bhavamishra (13th century), betel nut has been described as a therapeutic agent for leucoderma, leprosy, anemia obesity and de-worming properties. It has been used as vermifuge. Arecanut finds place in religious, social and cultural functions of India. The presence of the betel nut is a must in the ceremonial plate, as betel nuts are believed to increase prosperity. The nut is offered to guests, along with a betel leaf, as a mark of respect. Betel quid chewing (betel leaf, arecanut and lime) in India is at least 2,000 y old.

The chemical entities of this plant has been used as an anti-diabetic, blood pressure regulating activity, anti ulceogenic, antioxidant activity, anticonvulsant activity, C. N. S. stimulant activity, oxytocic activity, anti fertility, anthelmintic and antiviral activity etc [1]. To justify the classical assessed Mahabhautika dominancy in Pugaphala for the first time Puga is scientifically evaluated pharmacognostically and pharmaceutical study.

Ayurvedic properties [2]

Rasa: Kashaya

Guna: Ruksha, Guru

Veerya: Sheeta

Vipaka: Katu

Parts used: Fruit, Bark, Root

Chemical constituents

Alkaloids (Arecoline, Arecaidine, Guvacoline and Guvacine), tannin, lipids, volatile oils and gums.

\section{MATERIALS AND METHODS}

Collection of raw drugs

Raw drug was collected from the pharmacy department, I. P. G. T. and R. A., Gujarat Ayurveda University, Jamnagar. The botanical name and part used are given in table 1.

Table 1: Botanical name and part used

\begin{tabular}{lll}
\hline Sanskrit name & Botanical name & Part used \\
\hline Puga & Areca catechu & Fruit \\
\hline
\end{tabular}




\section{Pharmacognostical evaluation}

The raw drug was identified and authenticated by the Pharmacognosy laboratory, I. P. G. T. and R. A., Gujarat Ayurved University, Jamnagar. The identification was carried out based on morphological features, organoleptic characters and powder microscopy of the drug.

The initial purpose of study was to confirm the authenticity of the drug. First studied the dried powered under the Corl Zeiss Trinoculor microscope attached with camera with and without staining. Microphotographs were also taken under the microscope [3].

\section{Physicochemical parameters}

The drug was analyzed by using qualitative and quantitative parameters at Pharmaceutical Chemistry Laboratory of I. P. G. T. and R. A., Gujarat Ayurved University, Jamnagar [4].

\section{HPTLC}

Extract of Pugaphala was spotted on pre-coated silica gel GF 60254 aluminium plates as $5 \mathrm{~mm}$ bands, $5 \mathrm{~mm}$ apartand $1 \mathrm{~cm}$ from the edge of the plates, by means of a Camag Linomate $\mathrm{V}$ sample applicator fitted with a $100 \mu \mathrm{L}$ Hamilton syringe. Toluene $(7 \mathrm{ml})$, Ethyl acetate $(2 \mathrm{ml})$, Acetic acid $(1 \mathrm{ml})$ were used as the mobile phase. After development, Densitometric scanning was performed with a Camag T. L. C. scanner III in reflectance absorbance mode at $254 \mathrm{~nm}$ and $366 \mathrm{~nm}$ under control of win CATS software (V 1.2.1
Camag). The slit dimensions were $6 \mathrm{~mm} \times 0.45 \mathrm{~mm}$ and the scanning speed was $20 \mathrm{~mm} \mathrm{~s}-1$.

\section{OBSERVATIONS AND RESULTS}

\section{Pharmacognostical evaluation}

\section{Organoleptic characters}

The colour, odour, taste etc. of the powder was recorded and placed in table 2.

\section{Microscopic evaluation of Pugaphala powder}

The diagnostic characters observed under the microscope are Rhomboidal crystal, Epicarp cells, Iodine stained Simple Starch grain, Starch grain with hilum, Bordered pitted vessels, Group of Simple fiber, Bright yellowish content, Brown content, Oil globule, Lignified scleroids, Parenchyma cells with starch grain and Parenchyma cells (Microphotographs Plate 1.1-12)

\section{Physico-chemical parameters}

Drug was evaluated for various physicochemical parameters like loss on drying, water-soluble extract, alcohol soluble extract, total ash value, $\mathrm{pH}$ value. The results are placed at table 3 .

\section{HPTLC}

Methanol extracts of drugs were spotted on pre-coated silica gel at $254 \mathrm{~nm}$ and $366 \mathrm{~nm}$ Results are depicted in the table 4 and Plate 2 .

Table 2: Organoleptic features of fruit powder

\begin{tabular}{lll}
\hline S. No. & Organoleptic parameter & Result \\
\hline 1 & Texture & Course fine \\
2 & Colour & Chocolate Brown \\
3 & Odour & Slightly Aromatic \\
4 & Taste & Astringent \\
\hline
\end{tabular}

Table 3: Physicochemical parameters of Pugaphala

\begin{tabular}{lll}
\hline S. No. & Physico-chemical parameter & Result \\
\hline 1 & Loss on drying & $4.4 \% \mathrm{w} / \mathrm{w}$ \\
2 & Ash value & $3.8 \% \mathrm{w} / \mathrm{w}$ \\
3 & Water soluble extract & $18 \% \mathrm{w} / \mathrm{w}$ \\
4 & Methanol soluble extract & $16.4 \% \mathrm{w} / \mathrm{w}$ \\
5 & pH value & 6 \\
\hline
\end{tabular}

Table 4: Results of HPTLC of Pugaphala Churna

\begin{tabular}{|c|c|c|c|c|c|}
\hline \multirow[t]{3}{*}{ Track } & \multirow[t]{3}{*}{ Solvent system } & \multicolumn{4}{|c|}{ Observation under UV radiation } \\
\hline & & \multicolumn{2}{|c|}{$254 \mathrm{~nm}$} & \multicolumn{2}{|l|}{$366 \mathrm{~nm}$} \\
\hline & & No. of spots & Rf value & No. of spots & Rf value \\
\hline Pugaphala Churna & $\begin{array}{l}\text { Toluene }(7 \mathrm{ml}): \\
\text { Ethyl acetate }(2 \mathrm{ml}): \\
\text { Acetic acid }(1 \mathrm{ml})\end{array}$ & 7 & $0.01,0.21,0.46,0.48,0.76,0.81,0.95$ & 5 & $0.01,0.21,0.46,0.47,0.94$ \\
\hline
\end{tabular}

\section{DISCUSSION}

Acharya Charaka, Sushruta and Vagbhatta all had described the properties of Pancha Bhautika Dravyas by their Guna and Karma, out of them the Dravyas (drugs), which are predominant in properties of Guru, Sthoola, Kathina, Sthira, Sandra, Khara, Vishada etc. are Parthiva in Mahabhautika dominancy. They exert actions like Upachaya, Gaurava, Sanghaata, and Sthairya. Acharya Sushruta also described that Parthiva Dravyas are mostly Madhura and Kashaya in Rasa and are having downward movement instinctively due to their heaviness [5]. Ayurveda Sutra also mentioned that Kashaya Rasa is originates from Prithvi Mahabhuta [6].

Pugaphala also possess Kashaya Rasa, Guru, Ruksha Guna and Sheeta Veerya. So, by seeing its Rasa Panchaka, Pugaphala was selected as a Parthiva dominant Dravya and after that, pharmacognostical and pharmaceutical study were also supported the Prithvi dominance of
Pugaphala. In powder microscopy of Pugaphala, there are many structures which are hard, dense, compactly packed and gives physical strength like Rhomboidal crystal, Epicarp cells, Iodine stained Simple Starch grain, Starch grain with hilum, Group of Simple fiber, Lignified scleroid, etc. these characters are strongly dominated by Prithvi Mahabhuta.

Sclereids are a reduced form of sclerenchyma cells with highly thickened, lignified cellular walls that form small bundles of durable layers of tissue in most plants. The presence of numerous sclereids produces the gritty texture [7]. Sclereids are roughly isodiametric, and clumps of these "stone cells" give its distinctive grittiness.

Epicarp is a botanical term for the outermost layer of the pericarp (or fruit). The epicarp forms the tough outer skin of the fruit [8]. These features of Pugaphala can be correlated with Kathina, Sthira, Murta and Sthoola Swaroop of Prithvi Mahabhuta. 
In physico-chemical parameters loss on drying in Puga is $4.4 \% \mathrm{w} / \mathrm{w}$, this shows that on drying, loss is less because of dryness due to Khara, Vishada and Kathina Guna of Prithvi Mahabhuta. HPTLC also shows 7 spots on $254 \mathrm{~nm}$ while only 5 spots on $366 \mathrm{~nm}$, this shows that due to Sthira Guna of Prithvi Mahabhuta, drug was not spreads more.

Plate 1: Microscopic characters of Pugaphala Churna

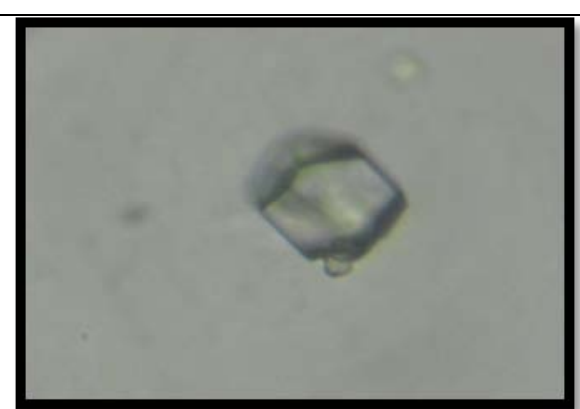

1. Rhomboidal crystal

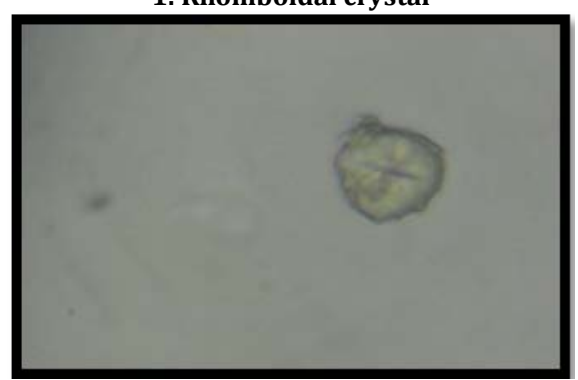

4. Starch grain with hilum

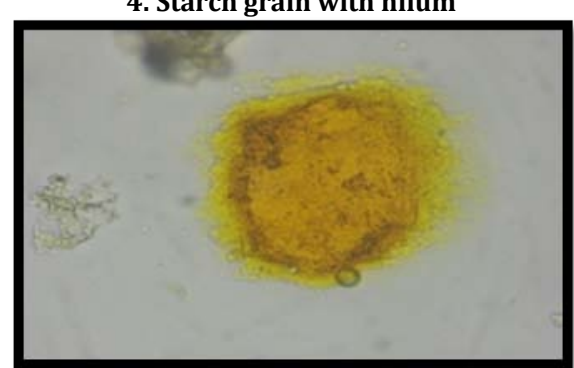

7. Bright yellowish cotent

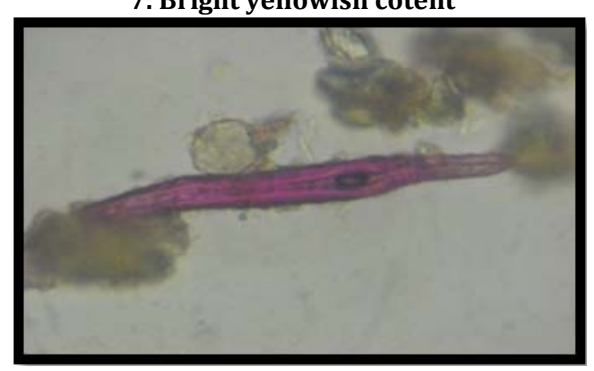

10. Lignified scleroid

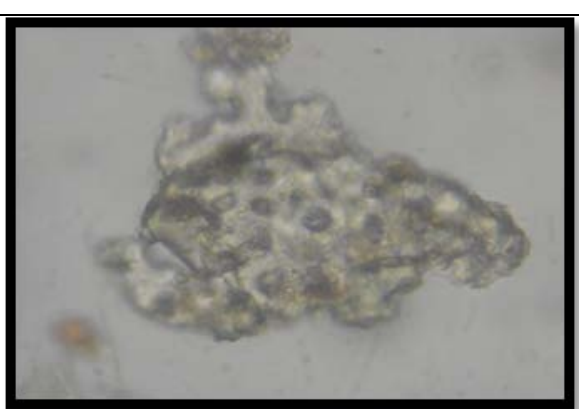

2. Epicarp cell

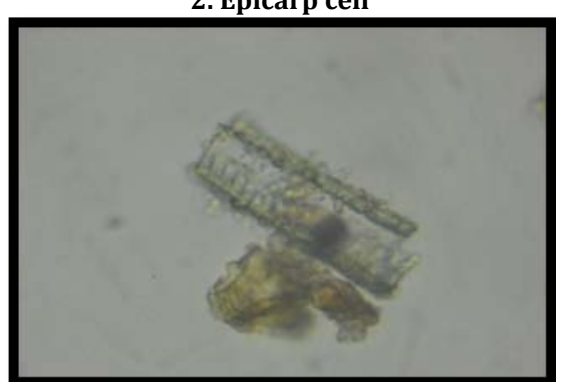

5. Bordered pitted vessel

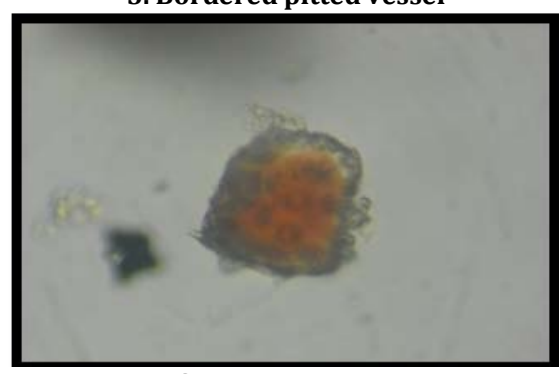

8. Brown content

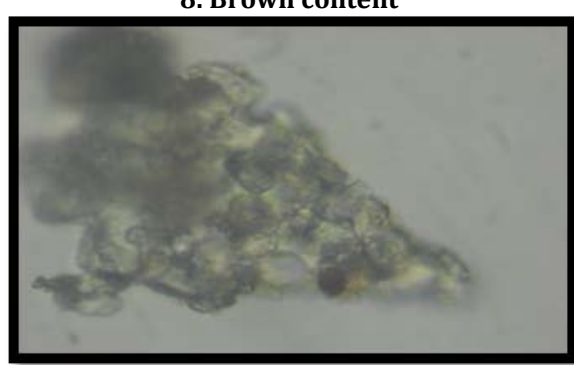

11. Parenchyma with starch grain

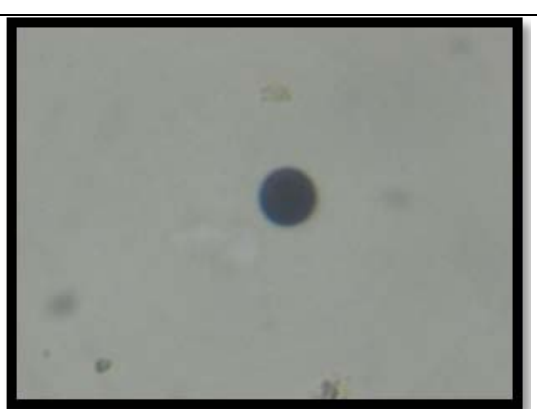

3. Stained Simple Starch grain

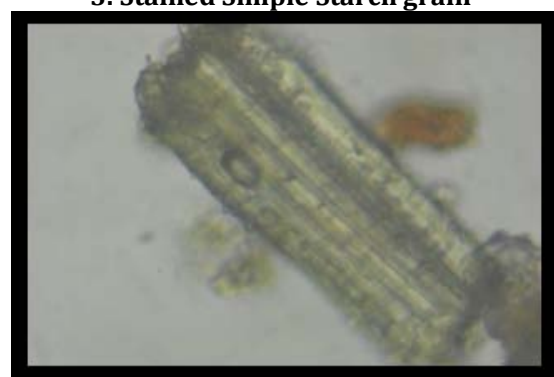

6. Group of Simple fiber

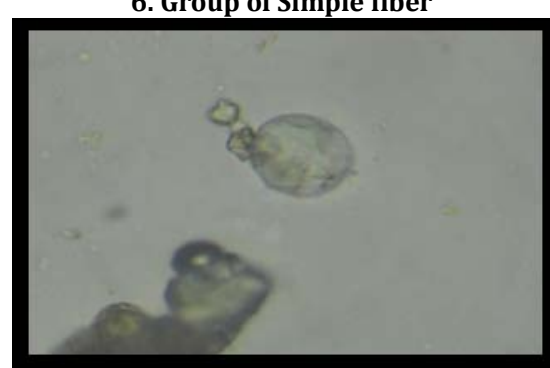

9. Oil globule

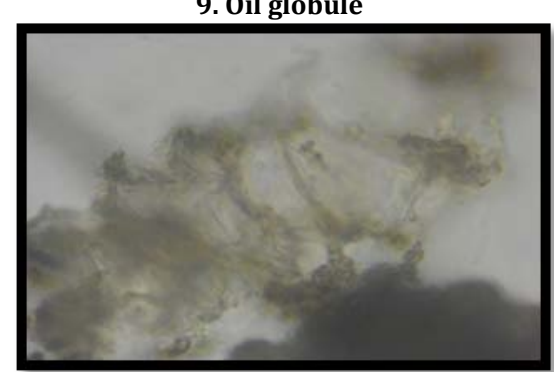

12. Parenchyma cells
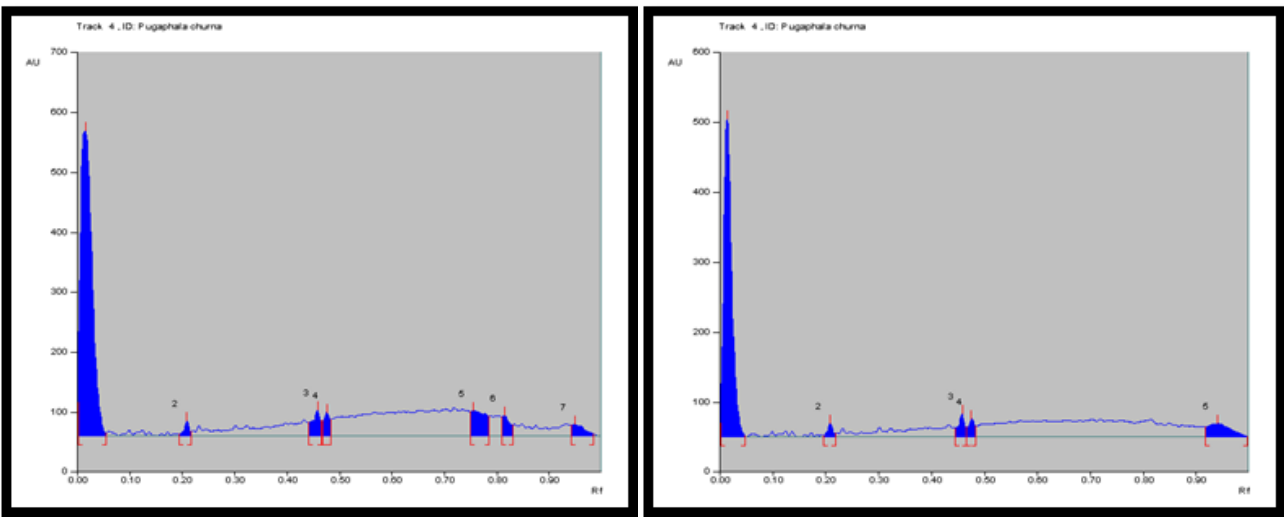

Plate 2: Densitogram of Pugaphala Churna 


\section{CONCLUSION}

Any Panchabhautika molecule has some shape (Akara). This shape is obtained because of compact and dense (Kathinya) of the elementary particles. This compactness and density (Kathinya) is also because of the material form (Murti) of that substance, obtained due to the generic principle Prithvi. Thus, Prithvi Mahabhuta is responsible for giving structure, shape and strength by their Sthoola, Sthira, Kathina, Sandra etc Guna and Sanghaata, Upachaya, Sthairya etc Karma. These Guna and Karma also assessed in Pugaphala by Pharmacognostical and Pharmaceutical study thus, dominance of Prithvi Mahabhuta in Pugaphala was assessed scientifically.

\section{AUTHORS CONTRIBUTIONS}

All the author have contributed equally

\section{CONFLICT OF INTERESTS}

Declared none

\section{REFERENCES}

1. Amudhan MS, Begum VH, Hebbar KB. A review on phytochemical and pharmacological potential of areca catechu L. seed. Int J Pharm Sci Res 2012;3:4151-7.

2. Bhavaprakasha Nighantu Purvakhanda. Chaukhambha bharti academy. Varanasi-Patna 1954;7:42-4.

3. Kokate CK, Purohit AP, Gokhale SB. Analytical pharmacognosy. 42nd ed. Pune: Nirali Prakashan; 2008.

4. The Ayurvedic Pharmacopia of India. Part I. Vol. I. Government of India, Ministry of Health and Family welfare. Department of Ayush; New Delhi; 2010. p. 160-2.

5. Sushruta: Sushruta Samhita with commentary of Dalhana, edited by vaidya jadavji Trikamji Acharya, Chaukhambha Surbharti Prakashan, Varanasi 8th edition, Sutra Sthana, chapter 41, verse 4, Reprint; 2014. p. 181.

6. Ayurveda Sutram Sabhashyam, by Yoganandnath, 8/3; 2013.

7. Sclereids. Available from: https://en.m.wikipedia.org. [Last accessed on 10 Mar 2018]

8. Fruit anatomy. Available from: https://en.m.wikipedia.org [Last accessed on 10 Mar 2018] 